\title{
The Dangers of "Safe Havens" for Kosovo
}

\author{
Bill Frelick
}

\begin{abstract}
Safe havens have been suggested as a means of providing protection and humanitarian assistance inside Kosovo. The track record on safe havens, however, suggests that they might not be as effective as they are touted to be. In fact, safe havens in Northern Iraq, Bosnia, and Rwanda lured displaced people into areas with a false sense of security, without actually keeping them from harm's way. Thus, the author concludes that in the absence of truly neutral safe havens created with the consent of all parties to a conflict, so-called safe havens represent a half-measure that serve to preclude would-be refugees from seeking asylum outside their country, while holding them in areas where the sovereignty of the government seeking to persecute them has not fundamentally been challenged.
\end{abstract}

\section{Résumé}

Les refuges temporaires ont été mis de l'avant comme moyen pour pourooir protection et assistance humanitaire d l'intérieur du Kosovo. Le dossier réel des refuges temporaires laisse cependant d conclure qu'ils ne sont probablement pas aussi efficaces que voulu. De fait les refuges temporaires du nord de l'Irak, de la Bosnie, et du Rwanda ont attiré les personnes déplacées dans des zones n'assurant qu'une illusion de sécurité, et cela sans leur épargner les dangers de la guerre. L'auteur conclut donc d la réalité effective de l'absenced'refuges temporairesvéritablement neutres, parce que constitués avec l'accord des deux parties en conflit. Cet état de fait a pour conséquence que les soi-disant refuges temporaires représentent une demi-mesurequi ne sert qu'd̀ empêcher des réfugiés potentiels de chercher abri hors de leur pays. On les parque plutôt dans des zones où la souve-

Bill Frelick is Senior Policy Analyst, U.S. Committeefor Refugees. raineté du gouvernement qui cherche d les persécuter n'a pas étéfondamentalement remise en question.

Although the highly visible mass exodus of refugees out of Kosovo has quickly drawn the world's attention, comparable numbers have been displaced inside Kosovo, out of the view of the world public. These are the most vulnerable: hungry, often without shelter, hiding from Serb forces intent on hunting them down and expelling them or worse. They are out of the reach of the humanitarian arms of the international community. No one is there to monitor their safety. No one is there to deliver food and humanitarian aid. In the absence of a military rescue, some have called for the creation of a safe haven inside Kosovo where the displaced could seek food and shelter. ${ }^{1}$

At first blush, the safe haven idea looks attractive: Keep people within their own country (easing theburden on host countries such as Macedonia and Albania, themselves economically and politically fragile); insist on citizens ${ }^{\prime}$ right to remain (thus opposing ethnic cleansing); and guarantee their safety where they are (a more limited military objective than removing all Serb military and police forces from Kosovo). In practice, however, safe havens havenot lived up to their name.

Safe havens have been tried during each of the major post-Cold War mass refugee exoduses:northem Iraq;eastern Bosnia; and southwestern Rwanda. Unfortunately, these examples provide little in the way of a model that the international community would want to replicate in Kosovo. Safe zones have compromised the right of peoplefleeing persecution to seek asylum outside their countries and, sooner or later, have put the very lives of those people whose safety the international community had guaranteed in grave danger.
The first and, relatively:speaking, the most successful of the safe havens was Operation Provide Comfort for the Kurds in northern Iraq. ${ }^{2}$ As a model for Kosovo, however, Operation Provide Comfort is flawed in a number of respects.

First, the Kurds innorthern Iraq were unwelcome in neighbouring Turkey and Iran, and therefore essentially had nowhere to flee. That is not the case for the ethnic Albanians of Kosovo. Although Macedonia has closed its border and pushed back refugees, Albania has welcomed the refugees, and setnolimit on the number it is willing to host. Albania needs massive assistance to make good on its offer, but the door is open.

Second, in 1991, Saddam Hussein was already beaten by caalition forces at the time the safe haven was declared. He was in no position to resist, and coalition ground troops did not have to fight their way into northern Iraq. At the time of writing, Milosevic was still in a strong position, and his troops were not likely to leave Kosovo without a fight.

Third, the part of Iraq that was designated as the safe area coincided with the territory where the Kurds were already concentrated and which they aspired to control. It would be comparable to declaring all of Kosovo, where ethnic Albanians comprised more than 90 percent of the population before the conflict, as a safe haven. Prior to Milosevic's defeat, if the international community set its sights on defending only a patch of Kosovan territory as a haven for persecuted civilians, this would likely be taken to signal its willingness to concedecontrol of the rest of Kosovo to Serb forces and, in effect, give the green light to cleansing those areas of their ethnic Albanian population.

Finally, Operation Provide Comfort never challenged Saddam Hussein's underlying sovereign claims to northern Iraq, and, in 1996, did nothing to stop his forces from penetrating the en- 
clave and kidnapping and killing scores of people in Erbil, the northern capital. The United States was forced to evacuate about 7,000 Iraqis, mostly Kurds, directly associated with U.S. humanitarian or political activities, but could provide no comfort to the hundreds of thousands of Kurds who had returned to the safe area from the Turkish and Iranian borders in 1991, and who, in 1996, found the borders to Turkey and Iran completely blocked. ${ }^{3}$ Operation Provide Comfort was not a promise made exclusively to the relatively few locals involved in the U.S. humanitarian operation. It was a promise of protection to all the civilians of the region, to the hundreds of thousands who sought to flee in 1991, a promise that could not be kept.

Likewise, the Bosnian safe areas offer little worth emulating. Arguably, the international community decided to declare these areas as safe less out of commitment to their security, than as a rationale for keeping would-berefugees in place and stemming the tide of refugees flowing into central and western Europe. ${ }^{4}$ UN Secretary-General Kofi Annan-at the time the UN Special Envoy for Bosnia - explained how limited the protection in the Bosnian safe areas actually was, saying that "the Security Council resolutions proclaiming the safe areas never asked the United Nations to either 'protect' or 'defend' them, merely to 'deter attacks' by its presence. ${ }^{\prime 5}$ Nevertheless, thinking that they would be protected, largenumbers of displaced people poured into UN Security Council-declared safe areas like Srebrenica, Zepa, and Gorazde. Soon, however, the overcrowded populations found themselves cut off, besieged, shelled, and starved. Unimpressed by the deterrenteffect of the UN presence, Serb forces closed in on Srebrenica and Zepa. With no clear Security Council mandate actually to protect noncombatants in the safe areas, UN peacekeepers failed to protect their charges. Serb soldiers separated men from their families, bussed the women and children out, and massacred the men. Far from drawing a line of protec- tion against ethnic cleansing, the Bosnian safe areas represented the international community's timidity in the face of aggression and brutality, a false promise that has undermined the international community's credibility and encouraged despots to test its resolve.

Finally, Operation Turquoise, $a$ "safe humanitarian zone" created by the French in southwest Rwanda for fleeing Hutus in 1994, shows the extent to which humanitarian rhetoric can be bent to political purposes. Operation Turquoise was a unilateral French initiative, endorsed by the UN Security Council, to create a safe haven in a corner of southwest Rwanda. Although the region had been the scene of Hutu acts of genocide directed against the Tutsi minority, France's intent, it appeared, was to provide protection and support tomembers of the deposed government: the pro-French architects of the genocide.

While the displaced Hutus in the humanitarian zone of southwestern Rwanda could be fed and sheltered, and did, indeed, avoid much of the misery experienced by their compatriots in the Zairian refugee camps in Goma, their situation wasnot safe. Armed extremist Hutu militia members operated openly in the zone, continuing to kill Tutsis living there and intimidating those Hutus living in camps whowanted togohome. Citing security concerns, and insisting that it was safe for displaced civilians to return, the new Rwandan authorities demanded that the camps in the southwest be closed, including Kibeho, the largest camp, which held up to 120,000 people.

In April 1995, after France had turned over the operation to UNAMIR, the Rwandan Patriotic Army (RPA) moved to force the displaced out of Kibeho, the largest displaced persons camp in the zone. Machete-wielding Hutu extremists in the camp provoked a violent confrontation with undisciplined RPA troops who, in full view of UN peacekeepers and international humanitarian relief organizations, committed a massacre-killing at least hundreds, and probably thousands, of people.
Erbil, Srebrenica, and Kibeho stand as monuments to the international community's failure to protect civilians it has pledged to protect. ${ }^{6}$ Do we add Djakovica or some other town in Kosovo to that list? Are there other alternatives? Would a safe haven in some part of Kosovo be any different from these three? Could its humanitarian purposes be divorced from the war aims of the parties to the conflict? Would Milosevic interpret the international community's willingness to draw a line around a specified area in Kosovo as an invitation to ethnically cleanse the surrounding areas? Would he interpret this to mean that his forces could burn and kill outside the safe area with impunity and herd the stragglers into those areas where they would remain at his mercy?

The Geneva Conventions specifically reference the establishment of neutralized zones in time of war, zones in fighting areas to shelter noncombatants whodonot perform any work of a military nature.? Such zones, the Geneva Conventions say, are to be established by agreement between the parties to the conflict. None of the post-cold War safe havens were, in fact, demilitarized, nor were any of them created with the consent of all parties to the conflict.

It is hard to imagine a safe haven in Kosovo that would meet Geneva Convention standards. Could the parties to the conflict agree to such a zone? War generally has a way of making the participating parties intransigent, but in this case intransigence also reflects Milosevic's war aim - to depopulate Kosovo of its ethnic Albanian population. Unlike wars between competing armies, Milosevic directs his forces not against NATO, but against civilians. It is not in his interests to create a neutral space within Kosovo where civilians could remain safely. He would only use such negotiations as a delaying tactic. Milosevic could achieve his aims simply by dragging his feet. During diplomatic deliberations, Serb police and paramilitaries would wage lower intensity war, further wearing down the civilianpopulation. And, if heever agreed to a safe haven, given the Bosnian experi- 
ence, there is no reason to believe he would honour its neutrality.

To be frank, however, there is no reason to believe that the Kosovo Liberation Army (KLA) would either. In all three cases cited above, armed elements identified with the protected civilian population were intermixed in the safe zones and waged hit-and-run operations from those sanctuaries. Such actions would be consistent with the KLA's provocative tactics during the course of the past year, which often goaded Serb police to strike back at their easiest and most favored target-civilians. Ironically, the continued presence of their KLA "protectors" in a safehaven would ensure that civilians in such enclaves would remain in harm's way.

But wouldn't an international force guard the safe zone? We come right back to basic war aims. One of NATO's key war aims is an international armed protective force in Kosovoto allow refugees to return and to permit Kosovars to decide their future. Milosevic's rejection of Rambouillet was largely based on his objection to any such international armed protective force. The bombing campaign is intended to cause Milosevic to withdraw his forces and invite in the armed peacekeepers. NATOawaits Milosevic's agueement to a "permissive environment" for peacekeeping forces. On the one hand, it seems unlikely that Milosevic would agree to armed peacekeepers in part of Kosovo at the same time that NATO is seeking to force him to accept peacekeepers throughout Kosovo. By the same token, it seems equally unlikely that NATO would willingly settle for their presence in a truncated part of a territory where only a month ago unarmed monitors from the Organization for Security and Cooperation had full access.

By all indications, large numbers of people are displaced within Kosovo without food. Their very survival dictates extraordinary measures, which leads to desperate proposals such as safe havens. But if safe havens are not the answer-and similar objections could be raised to food air drops or humanitarian corridors-what is left? Ef- forts of genuinely neutral third parties like the Swiss government, the Greek Doctors of the World organization, and the International Committee of the Red Cross, who are seeking permission to deliver food and humanitarian aid inside Kosovo should be applauded and supported. Yet while their chances for success surely rank higher than that of a safe haven (because their work has no territorial implications), they still are dependent on the permission of the parties to the conflict. In the absence of a NATObombing pause and the consent of Serbian ground forces, they are unlikely to mount a meaningful relief aid distribution.

The answer, therefore, is not in the hands of the humanitarians. Military action has marginalized the humanitarian role (although its importance in the margins, particularly in assisting refugees outside Kosovo, cannot be overstated). When the genocideappears to be ongoing - and all the evidence points in that direction for those who are trapped inside Kosovo-humanitarian actors are simply unequipped to stop the killing.

Forcemust bemetby force. Butclearly, by now, the military disconnect is obvious: the opposing military forces have not actually engaged each other. NATO planes and missiles strike at targetssuch as buildings, bridges, fuel depots, and air defences-only indirectly connected to the perpetrators of ethnic cleansing. Serb police and paramilitary units target unarmed civilians. NATO wages a war of attrition to wear down Serbia's military machine, but by the time it could succeed, the civilians trapped inside Kosovo-whether in safe or unsafe havens-will likely have succumbed to hunger, exposure, and disease.

Something has to change. NATO's tactics and timeline are out of synch with the human imperative and have failed to protect the people they were intended to help. To change course, NATOneeds to revise its objectives. One option, a very distasteful one, is to cut a deal with Milosevic for the partition of Kosovo, acknowledging NATO's unwillingness to reverse ethnic cleans- ing. ${ }^{8}$ The other is to set as NATO's priority the suppression of genocide and the rescue of civilians who are trapped inside Kosovo. ${ }^{9}$ This could not be accomplished by half measures such as safe havens, nor by the humanitarians, but by military force against military force.

To properly and realistically change course, another objective has to be addressed as well: abandonment of Kosovar autonomy as an objective, in favour of its independence. In no case has the international community's declaration of a safe haven explicitly challenged the sovereignty of the central government over the safe haven area. For example, the UN Security Council resolution that established the northern Iraq safe haven explicitly affirmed Saddam Hussein's sovereign authority over the area. This represents the ultimate contradiction and danger of safe havens. They lure people who are frightened, people who seek refuge outside the borders of the state that is persecuting them, into places where the international community continues to recognize the sovereignty of the very powers responsible for their persecution. Too often, such places become death traps because at the moment the sovereign power decides to clamp down, the internationals defer. Any idea of a safe haven, or of a Kosovo itself for that matter, that retains Serbian sovereignty over the ethnic Albanian population condemns that population to sit under a Damoclean sword. Whether NATO decides to defend Kosovo in whole or in part, the line separating Serb police from ethnic Albanian civilians must be clear, enforceable, and international.

\section{Notes}

1. Among the commentators calling for a safe haven inside Kosovo are: Roberta Cohen, "Uprooted Inside Kosovo Need Aid," Newsday, April 9, 1999; Princeton Lyman, "MakeaHaven at Home for the Refugees," Washington Post, April 12, 1999; Richard N. Hass, "Modest Objectives, Ambitious Means," Washington Post, April 19, 1999; ArthurC. Helton, "Vital Signs: We'reSeeing Refugees as Weapons," Washington Post, April 18, 1999. 
21.Bill Frelick, "The False Promise of Operation Provide Comfort: Protecting Refugees or Protecting State Power?" Middle East Report, May-June 1992

22.Bill Frelick, "U.S. Must Rescue Kurds Who Trusted U.S. Employers," Christian Science Monitor, November 8, 1996; Frelick, "America's Broken Promise," Atlanta Constitution, November 6, 1996; Frelick and Bob De V ecchi, "Don't Forsake the Kurdish Refugees," New YorkTimes,September21, 1996.

23.Bill Frelick, "'Preventive Protection' and the Right to Seek Asylum: A Preliminary Look at Bosnia and Croatia," International Journal of Refugee Law 4, no. 4 (1993).

24. Quoted by David Rieff, "Up the Organization: The Successful Failures of Kofi Annan," The New Republic, February 1, 1999.

25.For a fuller discussion of the three cases, see Bill Frelick, "Unsafe Havens: Reassessing Security in Refugee Crises," Harvard International Review II,no. 2 (Spring 1997).

7.' Fourth Geneva Convention, Article 14.

8. John J. Mearsheimer and Stephen Van Evera, "Redraw the Map, Stop the Killing," New York Times, April 19, 1999.

9. Bill Frelick, "Perspective on Kosovo: Genocide by Mass Starvation," Los Angeles Times, April 25, 1999. Cl

\section{Breaking Ground:}

\section{The 1956 Hungarian Immigration to Canada}

\section{Edited by Robert H. Keyserlingk}

\author{
Toronto: York Lanes Press, 1993; ISBN 1-55014-232-1; \\ 117 pages, $\$ 6.99$
}

This book is a collection of personal and archival-based memories on the selection, transport and settlement of about 40,000 Hungarian refugees in Canada in one year. It is a source of primary record as well as scholarly reflection on one of the most significant refugee movements to Canada after World War II-the 1956 Hungarian refugee movement.

Based on papers that were presented at a 1990 conference, the authors touch on the unique political, administrative and settlement features of this movement. The resulting work, edited by Professor Keyserlingk, is a unique mix of personal reminiscences and academic scholarship.

\section{Legitimate and Illegitimate Discrimination: New Issues in Migration}

\section{Edited by Howard Adelman}

Toronto: York Lanes Press, 1995; ISBN 1-55014-238-0; 287 pages, indexed; $\$ 22.95$

Freedom of movement: If themembers of a state are forced to flee, the legitimacy of that government is questionable. On the other hand, if members cannot or must leave, again the government is not democratically legitimate.

Immigration control: While limiting access and determining who may or may not become members of a sovereign state remains a legitimate prerogative of the state, the criteria, rules and processes for doing somustbe compatible with its character as a democratic state.

Legitimate and Illegitimate Discrimination: New Issues in Migration, edited by Professor Howard Adelman, deals with the question of legitimacy with cases studies from the Developing World, Europe, Australia, the United States, and Canada. CONTRIBUTORs:

Rainer Bauböck, Howard Adelman, Gaim Kibreab, A. Essuman-Johnson, Grant M. Farr, Lawrence Lam, Oscar SchiappaPietra, Tomas Hammar, Frédéric Tiberghien (in French), Lois Foster, and Arthur C. Helton.

$$
\text { Available from: }
$$

Centre for Refugee Studies

Fax: (416) 736-5837・ Email: refuge@yorku.ca 